\title{
En mann i 70-årene med langvarig myastenisk krise
}

\author{
En eldre mann med kjent myasthenia gravis ble innlagt som øyeblikke- \\ lig hjelp etter et par dager med nedsatt allmenntilstand, surklete res- \\ pirasjon og tung pust. Dette ble innledningen til et langt og komplisert \\ sykdomsforløp med uttalte respirasjonsproblemer. \\ Engelsk oversettelse på www.tidsskriftet.no
}

Se kommentar side 2185

\author{
Espen Benjaminsen \\ espen.benjaminsen@nlsh.no \\ Nevrologisk avdeling \\ Gunnar Waage Skjeflo \\ Knut Dybwik \\ Akuttmedisinsk avdeling \\ Nordlandssykehuset Bodø \\ Rolf Salvesen \\ Nevrologisk avdeling \\ Nordlandssykehuset Bodø \\ og \\ Institutt for klinisk medisin \\ Universitetet i Tromsø
}

Pasienten var en mann i 70-årene som utviklet symptomer på myasthenia gravis i form av varierende ptose, diplopi og tyggeclaudicatio. Blodprøve viste forhøyet nivå av acetylkolinreseptorantistoff på 6,8 nmol/l $(0,0-0,4 \mathrm{nmol})$. Han var tidligere blitt behandlet med kirurgi og stråleterapi for cancer recti Dukes klasse $B$ og hadde sigmoidostomi. Han var operert for ventralhernie, komplisert med tynntarmsperforasjon og påfølgende peritonitt og sårinfeksjon. Videre hadde han paroksystisk atrieflimmer og angina pectoris og ble behandlet for hypertensjon.

Et drøyt år etter at diagnosen myasthenia gravis ble stilt, fikk pasienten forverring av myasteniske symptomer, med svakhet $i$ nakke og underekstremiteter, dysartri og dyspné. Respirasjonsvanskene kunne delvis relateres til kronisk obstruktiv lungesykdom, som han fikk konstatert under innleggelse i sykehus. Det var ikke nødvendig med ventilasjonsstøtte. Symptomene ble bedre ved behandling med intravenøst immunglobulin (Ivlg), prednisolon og pyridostigmin.

Myasthenia gravis er en autoimmun sykdom med postsynaptisk skade i den nevromuskulære overgangen. Dette medfører økt trettbarhet og varierende kraftsvikt i rammet muskulatur. En stor andel av pasientene (rundt 90\%) får påvist acetylkolinreseptorantistoffer. Av de øvrige har om lag halvparten antistoffer rettet mot muskelspesifikk tyrosinkinase (MuSK).

På grunn av forstørret thymus ved CT thorax ble det utført torakoskopisk tymektomi etter forutgående plasmaferese. Histopatologisk fant man tymom, WHO-type B1. Inngrepet ble komplisert av peroperativ blødning og pneumothorax, slik at man måtte konvertere til anterolateral torakotomi. Postoperativt fikk han pneumothorax, det ble påvist luftlekkasje, og han måtte reopereres med kilereseksjon av høyre lunges mellomlapp og venstre overlapp. Han hadde postoperative smerter i brystet og ble derfor satt på gabapentin, et preparat vi antok ikke ville påvirke hans myasthenia gravis. Etter hvert kom han tilbake i god form, og med pyridostigmin $40 \mathrm{mg} \times 5$ og prednisolon $20 \mathrm{mg}$ hver annen dag ble han skrevet ut av nevrologisk sengepost uten vesentlige myastene symptomer.

To uker senere ble han innlagt som øyeblikkelig hjelp etter et par dager med nedsatt allmenntilstand, surkling i luftveiene og tungpustethet. Ved blikk oppad fikk han diplopi, men det ble ikke observert hengende øyelokk. Han hadde dysartri og økt trettbarhet i nakken i en slik grad at han bare maktet å løfte hodet et par sekunder om gangen. Toppstrømshastigheten (PEF) ved innkomst var bare $185 \mathrm{ml} / \mathrm{s}$, og da den senere samme dag falt ned mot $120 \mathrm{ml} / \mathrm{s}$, ble han intubert og tilkoblet respirator.

Dette ble innledningen på en lang og komplisert fase i hans sykdomsforløp, med uttalte respirasjonsproblemer.

Det ble gitt behandling med intravenøst immunglobulin 0,4 g/kg daglig i fem dager. Metoprolol, gabapentin, prednisolon og pyridostigmin ble seponert.
Mange medikamenter er rapportert å kunne forverre myasthenia gravis, blant disse er metoprolol og gabapentin. Pyridostigmin brukes som symptomatisk behandlling. Medikamentet kan gi kolinerg krise, særlig ved høye doser, og dermed ytterligere muskelsvakhet. I tillegg kan økt sekresjon i luftveiene opptre som bivirkning.

Etter to dager ble pasienten ekstubert, men pga. betydelig $\mathrm{CO}_{2}$-retensjon måtte han reintuberes og senere trakeostomeres. Tre dager etter første intubasjon utviklet han transmuralt hjerteinfarkt, med troponinverdi på 741 ng/l. Han fikk behandling med acetylsalisylsyre, klopidrogel, dalteparin, isosorbidmononitrat og gjeninnsetting av metoprolol.

Siden betablokker kan forverre myasthenia gravis og pasienten ble respiratorkrevende, ble metoprolol seponert. Etter grundig overveielse ble betablokaden gjeninnsatt av hensyn til hjertefunksjonen.

Samtidig ble det startet behandling mot pneumoni med cefuroksim, senere også metronidazol, basert på økende CRP-verdier, ekspektorat og mulig lungeinfiltrat på røntgen thorax. Etter avsluttet immunglobulinbehandling klarte han fremdeles ikke å trekke pusten, selv ved trykkstøttet ventilasjonsmodus, og hadde behov for kontrollert ventilasjon. Symptomatisk behandling med pyridostigmin ble gjeninnsatt, og han fikk igjen immunsuppressiv behandling med prednisolon $20 \mathrm{mg}$ annenhver dag.

Vi valgte en forsiktig oppstart av prednisolon, dels for ikke å indusere væskeansamling, som i verste fall kan gi postinfarkthjertesvikt, dels fordi høye doser glukokortikosteroider kan gi en forbigående forverring av myasthenia gravis.

Da prednisolon var trappet opp til $60 \mathrm{mg}$ daglig og pyridostigmin ble dosert $60 \mathrm{mg} \times 5$ daglig, uten nevneverdig effekt, ble det dag 19 utført neostigmintest. Under dekke av atropinsulfat ble 1,5 mg neostigmin injisert intramuskulært. Denne acetylkolinesterasehemmeren gir best effekt etter om lag 20 minutter, og man evaluerer om pasientens muskelstyrke og utholdenhet bedres. Han utførte uten problemer 75 håndkontraksjoner både før og etter injeksjonen. Ved ptosetest dekket øyelokket venstre pupill etter 36 sekunder, etter neostigmin først etter 44 sekunder, noe som ikke ble tolket som noen signifikant bedring. 


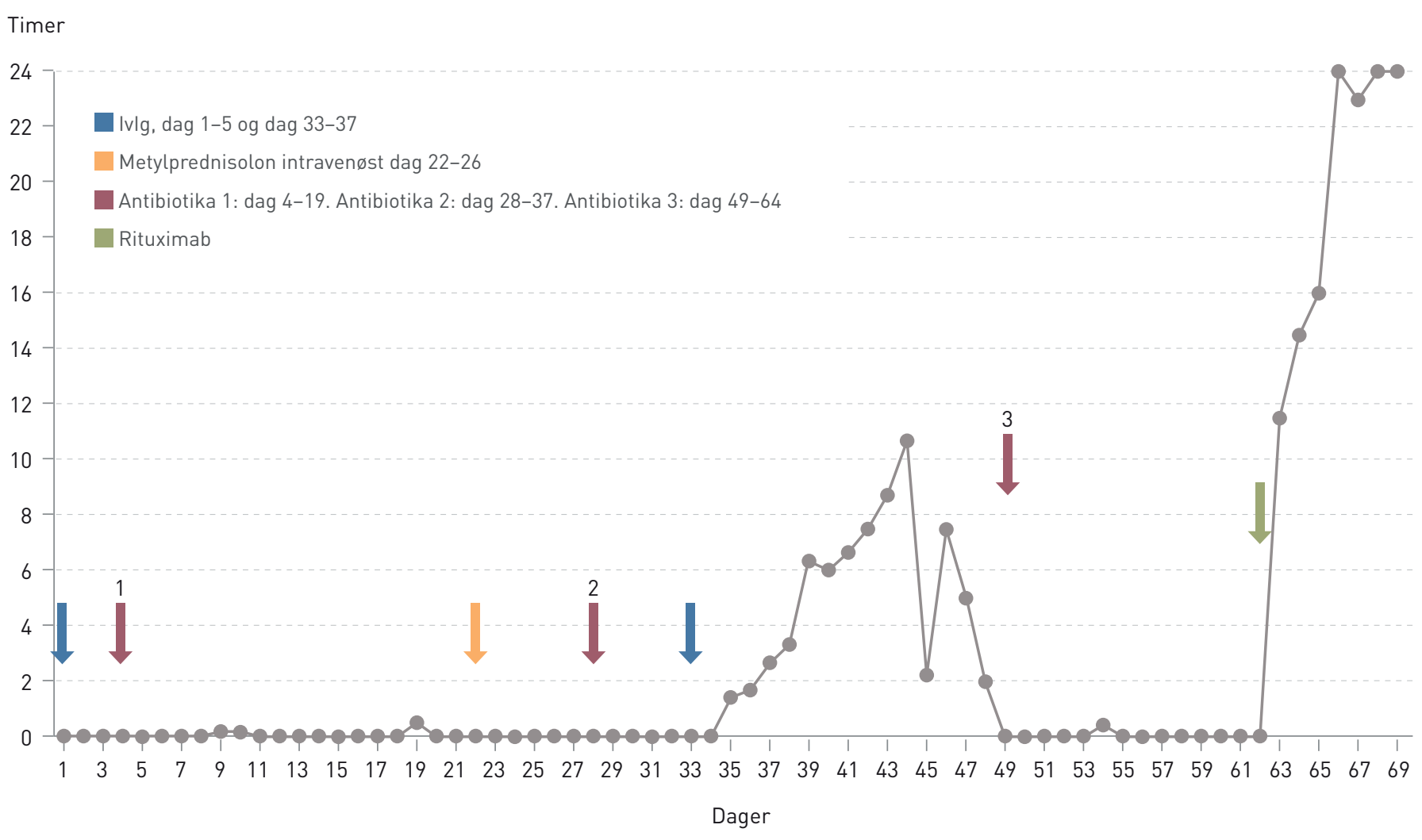

Figur 1 Antall timer uten respiratorstøtte per døgn hos en mann i 70-årene med myastenisk krise

Ventilasjonsevnen ble heller ikke bedret. Før neostigmininjeksjonen kunne han puste selv sammenhengende i 4 minutter, mens han en halv time etter injeksjonen bare klarte å puste selv i 90 sekunder.

Vi vurderte om den symptomatiske behandlingen var dosert høyt nok. Det at neostigmin ikke bedret pusteevnen, indikerte at økning av pyridostigmindosen ikke ville ha bedre effekt og at behandlingen fortsatt først og fremst måtte være immunsuppresjon.

Det ble nå gitt metylprednisolon $1000 \mathrm{mg}$ intravenøst daglig i fem dager, fremdeles uten bedring av pustefunksjonen. Det var holdepunkter for pneumoni, og pasienten fikk behandling med cefuroksim og metronidazol, som senere ble erstattet med piperacillin-tazobactam.

Etter 33 dagers respiratorbehandling ble det gjennomført en ny Ivlg-behandling over fem dager. Dag 43 begynte vi behandling med azatioprin, opptrappende til $150 \mathrm{mg}$ daglig. Pasienten ble nå gradvis i stand til å puste selv $i$ kortere og etter hvert lengre perioder, og 44 dager etter start av respiratorbehandling pustet han selv $i$ totalt 10 1/2 time i løpet av døgnet (fig 1).

Det ble deretter igjen en betydelig forverring da han dag 45 kun hadde egenrespirasjon to timer, neste dag bare én time og deretter ikke hadde egenrespirasjon i det hele tatt. Da det var økning i CRP-nivået til 107 $\mathrm{mg} / \mathrm{l}$, økt sekresjon fra luftveiene og infiltrat på røntgen thorax basalt venstre side, ble dette betraktet som ytterligere en respiratorassosiert pneumoni, som ble behandlet med klindamycin og ciprafloksacin.

Det kunne etter hvert oppleves som et dilemma at pasienten fikk omfattende immunsupprimerende behandling samtidig som han stadig fikk infeksjoner. Selv om det ikke var oppvekst i kulturer av blod og ekspektorat, valgte vi å gi antibiotikabehandling. Risikoen for bakteriell infeksjon er stor ved respiratorbehandling, og infeksjoner vil opprettholde funksjonssvikten ved myasthenia gravis. Samtidig må man være oppmerksom på at antibiotika kan forverre tilstanden.

Pasienten ble etter en uke afebril og uten sekresjon i luftveiene. CRP-nivået ble normalisert. Pustefunksjonen var likevel fortsatt så dårlig at han var helt avhengig av respirator. Han ga uttrykk for dyspné når respiratoren sto i trykkstøttet modus.

Respiratorbehandlingen i sykehusets intensivavdeling var nå blitt så langvarig at muligheten for hjemmerespirator ble diskutert. I Veileder $i$ habilitering og rehabilitering av mennesker med lungesykdommer fra 2000 er myasthenia gravis angitt som en av de nevrologiske tilstandene der dette kan være aktuelt. Oss bekjent er dette ikke tidligere forsøkt i Norge, men det skal ha blitt benyttet i bl.a. Danmark. Hjemmerespirator er svært krevende både økonomisk og i arbeidsinnsats, og bruk må planlegges og vurderes grundig.
Neostigmintest ble gjentatt dag 58, og ptosetesten ble nå bedømt å være positiv. Før injeksjonen holdt han øyelokkene oppe $i$ 2 minutter og 34 sekunder, mens de etter injeksjonen ennå ikke hadde begynt å sige etter 5 minutter. Pyridostigmindoseringen ble derfor økt fra $60 \mathrm{mg} \times 6$ til $90 \mathrm{mg} \times 6$.

Da respiratorbehandling, to Ivlg-kurer, metylprednisolon intravenøst, peroral prednisolon, azatioprin og pyridostigmin etter 62 dager ikke hadde bedret respirasjonsevnen, ble det besluttet gi behandling med $1000 \mathrm{mg}$ rituximab. Pustefunksjonen ble de neste dagene raskt bedre, og pasienten kunne etter kort tid flyttes til nevrologisk sengepost. Dag 68 ble trakeostomituben fjernet. Han kunne senere utskrives til hjemmet $i$ god allmenntilstand.

Rituximab ble gitt på ny etter 14 dager. Pasienten hadde ved undersøkelse et halvt år senere ingen symptomer eller funn som kunne indikere oppblussing av sykdommen.

\section{Diskusjon}

Med «myastenisk krise» forstår man forverring av myasteniske symptomer i en slik grad at intubasjon er nødvendig, eventuelt at ekstubering ikke kan skje innen 24 timer etter et kirurgisk inngrep (1). Ofte brukes begrepet videre, slik at det omfatter alle former for assistert ventilasjon.

En rekke forhold og faktorer kan forverre myasteniske symptomer og utløse en slik krise, bl.a. infeksjoner, kirurgiske inngrep og stoffskifteforstyrrelser. I tillegg er en rekke medikamenter beskrevet å kunne gi for- 
verring. Dette gjelder blant annet flere antibiotikatyper, medikamenter mot epilepsi, angst og smerte og medikamenter med kardiovaskulær effekt, slik som kalsiumkanalblokkere og betablokkere (inkludert øyedråper) (2). Listen er så omfattende at man nærmest må ha som utgangspunkt at ethvert legemiddel kan forverre tilstanden. Behandling av komplikasjoner og andre samtidige sykdomstilstander kan derfor være vanskelig.

I begynnelsen av 1960-årene ble mortaliteten ved myastenisk krise funnet å være $42 \%$, men den falt til $6 \%$ i slutten av 1970 årene (3) og har senere holdt seg relativt stabil. Over en tiårsperiode ble det ved Mayoklinikken i USA behandlet 40 pasienter med til sammen 46 tilfeller av myastenisk krise (4). Ekstubasjonssvikt ble definert som behov for reintubering, anlegging av trakeostomi eller død. Det var ekstubasjonssvikt i nesten halvparten av tilfellene, ved at reintubering måtte gjøres ni ganger, sju episoder krevde trakeostomi uten forsøk på ekstubering (11 trakeostomier totalt). Fire pasienter døde. Atelektase, lav pH og lav forsert vitalkapasitet (FVC) ved ekstubasjon var de viktigste prediktorene for reintubering.

Myasthenia gravis kan ramme ulike muskelgrupper i svært ulik grad. Muskulatur knyttet til øyelokkene og øyets bevegelser kan være affisert uten at øvrig muskulatur er involvert (okulær myasteni), men også andre former for fokal affeksjon er kjent. Det er rapportert om selektiv affeksjon av larynxmuskulatur med stemmebåndsparese og stridor (5). Hos hunder, som har tverrstripet muskulatur i oesophagus, er det beskrevet affeksjon av denne muskulaturen ved acetylkolinreseptorpositiv myasthenia gravis uten at det ble registrert svakhet for øvrig (6). Dette fører til oesophagusdilatasjon og refluks.

Muskelspesifikk tyrosinkinase (MuSK) er viktig i danning og vedlikehold av nevromuskulære overganger. Hos mus er det vist at ekspresjonen og nivået av dette proteinet varierer mellom ulike muskler. Ulike nivåer bestemmer evnen til å danne ektopiske klynger av acetylkolinreseptorer under gitte forhold (7). Det kan virke plausibelt at ulik ekspresjon av proteiner i ulike muskelceller fører til ulik plastisitet og sårbarhet. Vår pasient var etter kort tid sterk og utholdende i muskulaturen i ekstremitetene, men likevel helt avhengig av respirator pga. uttalt affeksjon av respirasjonsmuskulaturen.

Hos behandlingspersonalet var det en tendens til ulik tilnærming til behandlingen. Anestesiologene ønsket tidlig respirasjonstrening for raskere å avvenne pasienten fra ventilasjonsstøtten, mens nevrologene ønsket å avlaste respirasjonsmusklene inntil reseptorapparatet hadde fått anledning til å regenerere. Man kan ikke utelukke at fornuftig trening vil være gunstig for å hindre henfall av respirasjonsmuskulaturen ved langvarig respiratorbehandling. $(8,9)$. Det er likevel ingen tvil om at så lenge den nevro- muskulære overgangen i respirasjonsmuskulaturen ikke fungerer, vil pasienten ikke være i stand til å puste selv.

I behandling av myasthenia gravis søker man å optimalisere signaloverføringen i de nevromuskulære overgangene. Ved å gi acetylkolinesterasehemmer, som regel pyridostigmin, vil mengden av transmittersubstans $ø$ ke og virkningen på reseptorene vil bli kraftigere. Pyridostigmin blir som regel godt tolerert, men kan gi bivirkninger som kvalme, diaré, økt sekresjon i luftveiene, bradykardi og atrioventrikulær blokk (AV-blokk). Ved høye doser kan acetylkolinreseptorene bli desensitivisert, noe som vil gi muskelsvakhet, dvs. kolinerg krise.

I tillegg rettes behandlingen mot de patogene antistoffene for å redusere den postsynaptiske skaden. Kortikosteroider har en immunsupprimerende effekt som i de fleste tilfeller bedrer sykdomsforløpet. Det er imidlertid ikke ubetydelige bivirkninger forbundet med slik behandling, og ofte induseres vektøkning, diabetes og osteoporose. Azatioprin blir derfor ofte benyttet som steroidsparende immunsuppresjon. Andre alternativer kan være ciklosporin, cyklofosfamid eller metotreksat. Det er usikkert hvor stor effekt ekstirpasjon av thymus har hos eldre, men ved tymom er tymektomi alltid indisert (10).

Ved myastenisk krise blir den immunmodulerende behandlingen intensivert med intravenøst immunglobulin eller plasmaferese. Det kan også være aktuelt å gi høydose kortikosteroider intravenøst. Man må alltid søke å eliminere eventuelle utløsende faktorer.

Ulike nivåer av acetylkolinreseptorantistoff mellom ulike pasienter samsvarer ikke alltid med sykdommens alvorlighetsgrad, men endringer over tid hos samme person kan indikere endret sykdomsaktivitet. Vår pasient hadde ved diagnosetidspunktet et antistoffnivå på $6,8 \mathrm{nmol} / 1$. Etter 55 dagers forløp av den myasteniske krisen var nivået ti ganger så høyt, $68,0 \mathrm{nmol} / 1$. To dager senere var nivået $59,0 \mathrm{nmol} / 1$.

Flere forhold kan ha medvirket til at respirasjonsevnen til slutt bedret seg hos vår pasient. Det ble gitt flere antibiotikakurer, og infeksjonene ble slått tilbake. Den forsterkede symptomatiske behandlingen med pyridostigmin kan ha hatt en viss betydning, men var neppe avgjørende, og forbedringen kom flere dager etter siste doseøkning. Hovedårsaken var nok den langvarige og etter hvert omfattende immunsuppressive behandlingen. Ved ekstubasjon sto pasienten på prednisolon i høy dose, azatioprin var introdusert og det var gjennomført to IvIg-kurer. Rituximab ble gitt seks dager før ekstubasjonen.

Rituximab er et monoklonalt antistoff rettet spesifikt mot CD20-positive B-celler og brukes ved lymfom, kronisk lymfatisk leukemi og alvorlige revmatologiske sykdommer. Det er kasuistiske rapporter om gunstig effekt også ved myasthenia gravis (11). Fra Sahlgrenska Sjukhuset er det beskrevet fem pasienter med alvorlig myasthenia gravis som fikk slik behandling. Alle fikk markant bedring, men den var langsom og gradvis (12). Bedringen hos vår pasient var langt raskere, og det er usikkert hvor mye som kan tilskrives rituximab. Det er også publisert en kasuistikk der en 31 år gammel kvinne med refraktær myasthenia gravis og respirasjonssvikt ble behandlet $\mathrm{i}$ flere måneder med $\mathrm{i}$ alt tre kurer med intravenøst immunglobulin, prednisolon, cyklofosfamid og pyridostigmin, uten varig effekt. Etter behandling med rituximab var det rask bedring av pustefunksjonen, men tidsforløpet er ikke nøyaktig angitt (13).

\section{Konklusjon}

Det beskrevne sykdomsforløpet viser at funksjonstapet ved myastenisk krise kan være svært langvarig. Det er viktig å huske at tilstanden i de aller fleste tilfeller er reversibel. Det finnes ingen kontrollerte studier med rituximab ved myasthenia gravis, men det er holdepunkter for at medikamentet kan ha god effekt ved alvorlige tilfeller.

Pasienten har gitt samtykke til at artikkelen blir publisert.

\section{Espen Benjaminsen (f. 1971)}

er spesialist i nevrologi og overlege.

Forfatter har fylt ut ICMJE-skjemaet og oppgir ingen interessekonflikter.

\section{Gunnar Waage Skjeflo (f. 1982)}

er lege i spesialisering i anestesiologi.

Forfatter har fylt ut ICMJE-skjemaet og oppgir ingen interessekonflikter.

\section{Knut Dybwik (f. 1961)}

er intensivsykepleier og dr.philos. med respiratorbehandling i og utenfor sykehus som spesialkompetanse.

Forfatter har fylt ut ICMJE-skjemaet og oppgir ingen interessekonflikter.

\section{Rolf Salvesen (f. 1952)}

er avdelingsoverlege og professor i nevrologi. Forfatter har fylt ut ICMJE-skjemaet og oppgir ingen interessekonflikter.

\section{Litteratur}

1. Bedlack RS, Sanders DB. On the concept of myasthenic crisis. J Clin Neuromuscul Dis 2002; 4: 40-2.

Chaudhuri A, Behan PO. Myasthenic crisis. QJM 2009; 102: 97-107.

3. Cohen MS, Younger D. Aspects of the natural history of myasthenia gravis: crisis and death. Ann N Y Acad Sci 1981: 377: 670-7.

4. Seneviratne J, Mandrekar J, Wijdicks EF et al. Predictors of extubation failure in myasthenic crisis. Arch Neurol 2008; 65: 929-33.

5. Kanemaru S, Fukushima H, Kojima $\mathrm{H}$ et al. A case report of myasthenia gravis localized to the larynx. Auris Nasus Larynx 2007; 34: 401-3

6. Shelton GD, Willard MD, Cardinet GH 3rd et al. Acquired myasthenia gravis. Selective involvement of esophageal, pharyngeal, and facial muscles. J Vet Intern Med 1990; 4: 281-4

7. Punga AR, Maj M, Lin S et al. MuSK levels differ between adult skeletal muscles and influence postsynaptic plasticity. Eur J Neurosci 2011; 33: 890-8. 
8. Levine S, Nguyen T, Taylor $\mathrm{N}$ et al. Rapid disuse atrophy of diaphragm fibers in mechanically ventilated humans. N Engl J Med 2008; 358: 1327-35.

9. Martin AD, Smith BK, Davenport PD et al. Inspiratory muscle strength training improves weaning outcome in failure to wean patients: a randomized trial. Crit Care 2011; 15: R84.

10. Sathasivam S. Current and emerging treatments for the management of myasthenia gravis. Ther
Clin Risk Manag 2011: 7: 313-23

11. Ibrahim H, Dimachkie MM, Shaibani A. A review: the use of rituximab in neuromuscular diseases. $J$ Clin Neuromuscul Dis 2010; 12: $91-102$

12. Lindberg C, Bokarewa M. Rituximab for severe myasthenia gravis - experience from five patients. Acta Neurol Scand 2010; 122: 225-8

13. Lau AY, Chan AY, Mok VC. Refractory bulbar and respiratory dysfunction in a young Chinese woman with seronegative, muscle-specific tyrosine kinase antibody-positive myasthenia gravis: response to cyclophosphamide and rituximab treatment. Hong Kong Med J 2011; 17: 77-9.

Mottatt 17.11. 2011, første revisjon innsendt 24.2 2012, godkjent 21.6. 2012. Medisinsk redaktør Petter Gjersvik.

\section{Kommentar}

\section{Vanskelig behandling - mange valg}

Myasthenia gravis er en autoimmun sykdom som rammer den nevromuskulære synapse. Sykdommen forårsakes i de fleste tilfellene av antistoff mot nikotinerg acetylkolinreseptor (AChR) på den postsynapstiske muskulære del av synapsen. I sjeldne tilfeller er sykdommen forårsaket av antistoff mot muskelspesifikk tyrosinkinase (MuSK) eller mot lipoproteinrelatert protein 4 (LRP4).

Myasthenia gravis er en relativt sjelden sykdom, med en prevalens på ca. 150 tilfeller og en insidens på rundt 10-15 nye tilfeller per million innbyggere per år. Sykdommen manifesterer seg med okulære symptomer som diplopi og ptose, bulbære symptomer som dysartri og dysfagi og generaliserte symptomer med pareser i nakkemuskulatur og proksimal ekstremitetsmuskulatur. Typisk er fluktuerende symptomer med bedring etter hvile.

Behandlingen av myasthenia gravis er symptomatisk ved å hemme ACh-esterase i synapsen med pyridostigmin og immunologisk med kortikosteroider eller annen immunsuppresjon (1). Tymektomi er aktuelt hos pasienter med tymom (ca. 10-15\%) og hos dem med generalisert myasthenia gravis. Vedlikeholdsbehandling skjer som regel med pyridostigmin og lavdose prednisolon, eventuelt med azatioprin som steroidsparende medikament. En rekke andre immunsuppressive medikamenter kan forsøkes, slik som mykofenolatmofetil, rituximab, metotreksat eller ciklosporin $(1,2)$.

I dette tilfellet beskrives en pasient med kjent myasthenia gravis og myastenisk krise. En rekke forhold kan forverre myasthenia gravis, slik som ulike medikamenter som påvirker den nevromuskulære synapse - og ikke minst infeksjoner, som var tilfellet her. Behandling av myastenisk krise er intravenøst immunglobulin (IvIg) eller plasmautskiftning. Disse behandlingene gir rask bedring, og studier viser at de har likeverdig effekt. Høydose kortikosteroider kan også bedre myastenisk krise hvis de forutgående behandlinger ikke har hatt tilstrekkelig effekt. Dette ble gitt ut i behandlingsforløpet hos aktuelle pasient i tillegg til antibiotika for pneumoni. Det er også vist at rituximab kan bedre forløpet, og dette medikamentet bør forsøkes hvis ikke intravenøst IgG eller kortikosteroider har gitt resultater $(2,3)$. Pasienten ble markant bedre etter sistnevnte behandling.

Denne sykehistorien illustrerer viktige poenger. Myastenisk krise kan være vanskelig å behandle. Immunsuppressiv behandling må ofte gis på tross av pågående infeksjon.
Intravenøst IgG, kortikosteroider og rituximab er aktuelle medikamenter i angitt rekkefølge ved myastenisk krise.

\section{Christian Vedeler}

christian.vedeler@helse-bergen.no

Christian Vedeler (f. 1958) er overlege ved Nevrologisk avdeling, Haukeland universitetssykehus, og professor i nevrologi ved Universitetet i Bergen.

Forfatter har fylt ut ICMJE-skjemaet og oppgir ingen interessekonflikter.

\section{Litteratur}

1. Skeie GO, Apostolski S, Evoli A et al. Guidelines for treatment of autoimmune neuromuscular transmission disorders. Eur J Neurol 2010; 17: 893-902.

2. Díaz-Manera J, Rojas García R, Illa I. Treatment strategies for myasthenia gravis: an update. Expert Opin Pharmacother 2012; 13: 1873-83.

3. Gilhus NE, Owe JF, Hoff JM et al. Myasthenia gravis: a review of available treatment approaches. Autoimmune Dis 2011. E-publisert 5.10.2011.

Manuskriptet ble mottatt 14.8. 2012 og godkjent 29.8. 2012. Medisinsk redaktør Petter Gjersvik. 